\title{
SUBSTANSI PENGATURAN HUKUM DAERAH KEPULAUAN
}

\author{
Johanis Leatemia ${ }^{1}$
}

\begin{abstract}
Archipelagic regions (province, regencies and municipalities) is a place characteristic of breadth of territorial sea consisted of archipelagos. The archipelagic regions play important roles to a state (Indonesia) to be recognized as an archipelagic state. However, it does not regulate properly in Indonesian regulations.
\end{abstract}

Keywords: state of the islands, settings law, regional islands.

\begin{abstract}
Abstrak
Daerah kepulauan (provinsi, kabupaten dan kota) adalah karakteristik tempat luasnya laut teritorial terdiri dari kepulauan. Daerah kepulauan memainkan peran penting untuk sebuah negara (Indonesia) harus diakui sebagai negara kepulauan. Namun, tidak mengatur dengan baik dalam peraturan Indonesia.
\end{abstract}

Kata kunci: negara kepulauan, pengaturan hukum, daerah kepulauan.

\section{Pendahuluan}

Laut pada dasarnya mempunyai banyak fungsi, baik sebagai sumber makanan bagi umat manusia, jalan raya perdagangan, sarana penaklukan, tempat pertempuran, tempat bersenang-senang dan rekreasi maupun alat pemersatu bangsa. Fungsi laut sebagai alat pemersatu bangsa maupun sumber kekayaan alam, telah menjadi perhatian Pemerintah dan masyarakat Indonesia sejak masa penjajahan, terutama setelah Pemerintah Belanda memberlakukan Territorialle Zee en Marrittimme Kringen Ordonantie (TZMKO) sebagaimana diatur dalam Staatblaad 1939 Nomor 442. Di dalam Pasal 1 ayat (1) TZMKO tersebut dinyatakan bahwa "lebar laut wilayah Indonesia adalah 3 mil laut, diukur dari garis air rendah dari pulau-pulau

1 Penulis adalah Dosen Fakultas Hukum Universitas Pattimura, Ambon. Alamat Korespondensi: Fakultas Hukum Universitas Pattimura, Jln. Ir. M. Putuhena (Kampus Poka) Ambon. 
yang termasuk dalam daerah Indonesia". ${ }^{2}$ Ketentuan ordonansi ini sangat merugikan Indonesia sebagai suatu Negara Kesatuan dengan karakteristik kepulauan karena, di dalam wilayah Indonesia terdapat kantong-kantong laut bebas akibat cara pengukuran lebar laut teritorial yang menyebabkan pulau-pulau mempunyai laut wilayah sendiri-sendiri.

Pengukuran lebar laut seperti dikemukakan di atas, menyebabkan, (1) dari segi keamanan, bentuk laut yang demikian akan menimbulkan banyak kesulitan dalam melakukan pengawasan; (2) dari segi pelayaran, adanya kantong-kantong laut lepas dengan rezim kebebasannya dapat membayakan keutuhan wilayah nasional, karena kapal-kapal dari semua negara dapat melakukan pelayaran maupun perang; (3) dari segi ekonomi, sistem perairan yang lama sangat merugikan Indonesia, karena negaranegara asing dengan kemajuan teknik penangkapan ikan dapat menghabiskan sumber-sumber ikan di laut sekitar pantai; (4) dari segi politik, ketentuan hukum laut yang lama sangat membahayakan keutuhan wilayah dan kesatuan nasional Indonesia, karena bangsa Indonesia merasa diri terpisah-pisah satu sama lain. ${ }^{3}$

Perubahan fundamental ketentuan hukum laut Indonesia sebagai suatu negara kepulauan terasa perlu dilakukan, dilatarbelakangi oleh perkembangan hukum laut internasional yang ditandai dengan, (1) Proklamasi Presiden Truman tahun 1945 tentang "Continental Shelf"; (2) Proklamasi Presiden Truman tahun 1945 tentang Perikanan; (3) Sengketa perikanan antara Inggris dan Norwegia (Keputusan Mahkamah Internasional tahun 1951); dan (4) Klaim-klaim 200 mil oleh Chile, Ecuador dan Peru. ${ }^{4}$

Atas dasar perkembangan dalam masyarakat internasional, maka pada tanggal 13 Desember 1957, Pemerintah Republik Indonesia telah mengeluarkan Deklarasi Djuanda mengenai Perairan Indonesia, yang isinya menegaskan, (1) segala perairan di sekitar, diantara dan yang menghubungkan pulau-pulau atau bagian pulau-pulau yang termasuk daratan Republik Indonesia dengan tidak memandang luas atau lebarnya adalah bagian-bagian yang wajar dari pada wilayah daratan negara Republik Indonesia dan dengan demikian merupakan bagian dari perairan nasional yang berada di bawah kedaulatan mutlak Negara Republik Indonesia; (2) Lalu lintas

${ }^{2}$ Boer Mauna, "Hukum Internasional, Pengertian, Peranan dan Fungsi Dalam Era Dinamika Global", (Bandung: Alumni, 2003), hal. 338.

${ }^{3}$ Ibid., hal. 339-340.

${ }^{4}$ Mochtar Kusumaatmadja, "Hukum Laut Internasional", (Bandung: Binacipta, 1986), hal. 81108. 
damai di perairan pedalaman ini bagi kapal-kapal asing terjamin selama dan sekedar tidak bertentangan dengan kedaulatan dan keselamatan Negara Indonesia; dan (3) Penentuan batas laut teritorial yang lebarnya 12 mil yang diukur dari garis-garis yang menghubungkan titik-titik yang terluar pada pulau-pulau Negara Republik Indonesia akan ditentukan dengan undang-undang.

Di dalam Deklarasi Djuanda, Pemerintah Indonesia menegaskan "Prinsip Negara Kepulauan" (Archipelagic State Principles), yang memandang wilayah laut dan darat sebagai suatu kesatuan yang utuh sesuai filosofi "Tanah-Air". Konsepsi Negara Kepulauan (Archipelagic State) didasarkan pada konsepsi "archipelago" berarti laut dimana banyak terdapat pulau-pulau. Dalam "archipelago" tersebut rasio laut atau air adalah lebih besar dari pada daratan (pulau), tetapi keduanya dianggap sebagai suatu kesatuan. Dengan demikian, pengertian yang paling penting dalam konsepsi archipelago adalah kesatuan antara laut dan darat (serta udara di atasnya), dimana ratio laut adalah lebih besar dari ratio darat ${ }^{5}$. Dengan Prinsip Negara Kepulauan, Pemerintah Indonesia memasuki pelaksanaan Konferensi Hukum Laut Internasional III yang melahirkan United Nations Convention on The Law of The Sea (UNCLOS) 1982. Negara Kepulauan menurut UNCLOS adalah suatu Negara yang seluruhnya terdiri dari satu atau lebih kepulauan dan dapat mencakup pulau-pulau lain (Pasal 46 ayat 1 Konvensi Hukum Laut 1982). Wujud suatu Negara Kepulauan ditentukan berdasarkan penentuan garis pangkal lurus kepulauan (archipelagic straight baseline) sebagaimana ditegaskan dalam Pasal 47 ayat (1) Konvensi Hukum Laut 1982 bahwa:

An archipelagic State may draw straight archipelagic baselines joining the outer most points of the outermost island and drying reefs of the archipelago provided that within such baselines are included the main islands and an area in which the ratio of the area of the water to area of the land, including atolls, is between 1 to 1 and 9 to 1 .

Penarikan garis pangkal lurus kepulauan di atas dilakukan bagi Negara dengan karakteristik kepulauan. Menurut Etty R. Agoes, ${ }^{6}$ bahwa ketentuan di atas tidak

\footnotetext{
${ }^{5}$ Hasyim Djalal, "Perjuangan Indonesia Di Bidang Hukum Laut", (Bandung: Binacipta 1979), hal. 70 .
}

${ }^{6}$ Etty R. Agoes, Praktik Negara-Negara Atas Konsepsi Negara Kepulauan, dalam Jurnal Hukum Internasional, Lembaga Pengkajian Hukum Internasional Fakultas Hukum Universitas Indonesia, Jakarta, Volume 1n Nomor 3, April 2004, ha.1 181. 
menjadikan penarikan garis pangkal lurus kepulauan sebagai suatu kewajiban, melainkan hanya sebagai suatu pilihan. Negara kepulauan mempunyai kebebasan untuk menetapkan cara penarikan garis pangkal lain sepanjang tidak bertentangan dengan Konvensi 1982. Garis pangkal lain dalam konteks ini, pada dasarnya diberlakukan pada Negara yang tidak memiliki karakteristik kepulauan yaitu penarikan garis pangkal biasa (normal baseline) atau garis pangkal lurus (straight baseline) sebagaimana dimaksud pada Pasal 5 dan Pasal 7 ayat (1) Konvensi Hukum Laut 1982.

Konvensi Hukum Laut 1982 menerapkan "prinsip pembedaan" dalam menentukan lebar laut teritorial suatu negara. Bagi negara dengan karakteristik kontinental dipergunakan garis pangkal biasa (normal baseline) untuk mengukur lebar laut teritorial, bagi negara-negara kontinental dengan karakteristik teluk yang lebar atau terdapat pulau-pulau di depan pantainya dipergunakan garis pangkal lurus (straight baseline) untuk mengukur lebar laut teritorialnya, sedangkan bagi negaranegara dengan karakteristik kepulauan dapat dipergunakan garis pangkal lurus kepulauan (archipelagic straight baseline) untuk mengukur lebar laut teritorialnya.

Pasal 25A UUDNRI TH 1945 menegaskan bahwa "Negara Kesatuan Republik Indonesia adalah sebuah Negara kepulauan yang berciri nusantara dengan wilayah yang batas-batas dan hak-haknya ditetapkan dengan undang undang". Adanya pasal ini menurut Jimly Assiddiqie, ${ }^{7}$ menampakkan tiga hal, pertama, menegaskan bahwa Negara Indonesia memiliki wilayah hukumnya sendiri sebagai sebuah Negara merdeka dan berdaulat. Kedua, pasal ini juga menegaskan bahwa wilayah hukum Negara Indonesia itu, batas-batas dan hak-hak yang terdapat di dalamnya diatur dengan undang-undang. Artinya, pemerintah dan siapapun juga tidak berhak menambah atau mengurangi wilayah Negara itu tanpa persetujuan rakyat yang dituangkan dalam undang-undang. Ketiga, penetapan batas-batas wilayah beserta hak-haknya itu dalam undang-undang juga tidak boleh dipahami bersifat sepihak tanpa mengindahkan norma-norma yang berlaku di dunia internasional.

Sebagai suatu negara kesatuan dengan karakteristik kepulauan Indonesia menganut asas desentralisasi, sehingga kepada daerah diberikan kesempatan dan kekuasaan untuk mengatur dan mengurus rumah tangganya sendiri (otonomi daerah) yang dinamakan dengan daerah otonom. Dalam hal ini, Pemerintah Pusat mempunyai wewenang untuk menyerahkan sebagian kekuasaannya kepada daerah berdasarkan hak otonomi, tetapi pada tahap terakhir kekuasaan tertinggi tetap di

\footnotetext{
${ }^{7}$ Jimly Assiddiqie, "Konsolidasi Naskah UUD 1945 Setelah Perubahan Keempat, (Jakarta: Pusat Studi Hukum Hukum Tata Negara, Fakultas Hukum UI, 2002), hal. 47.
} 
tangan pemerintah pusat. Jadi kedaulatannya, baik kedaulatan ke dalam maupun kedaulatan ke luar, sepenuhnya terletak pada pemerintah pusat. ${ }^{8}$

Dalam negara kesatuan, bagian-bagian negara lazim disebut dengan daerah (gebiedsdeel) dimaksudkan lingkungan yang dijelmakan dengan membagi suatu kesatuan lingkungan yang disebut wilayah (gebied). Dengan kata lain, istilah daerah bermakna bagian atau unsur dari suatu lingkungan yang lebih besar sebagai suatu kesatuan. ${ }^{9}$ Hal ini sesuai dengan Pasal 18 ayat (1) UUDNRI TH 1945 yang menegaskan bahwa "Negara Kesatuan Republik Indonesia dibagi atas daerah-daerah provinsi dan daerah provinsi itu dibagi atas kabupaten/kota, yang tiap-tiap provinsi, kabupaten dan kota itu mempunyai pemerintahan daerah yang diatur dengan undang undang". Menurut Jimly Asshiddiqie ${ }^{10}$, penggunaan istilah "dibagi atas" ini dimaksudkan untuk menegaskan bahwa hubungan antara pemerintah pusat dan daerah bersifat hirarkis dan vertikal. Hal ini bebeda dengan Negara Federal maupun Konfederasi.

Dari bentuk-bentuk utama pemencaran penyelenggaraan Negara dan pemerintahan, akan dijumpai paling tidak tiga bentuk hubungan antara pusat dan daerah menurut dasar, (1) dekonsentrasi teritorial; (2) otonomi teritorial; dan (3) federal. ${ }^{11}$ Bagi suatu Negara kesatuan dengan karakteristik kepulauan, maka idealnya hubungan pusat dan daerah dilakukan menurut otonomi territorial, karena dapat dilakukan melalui, (1) undang undang menetapkan secara tegas berbagai fungsi pemerintahan (administrasi negara) sebagai urusan rumah tangga daerah; (2) Pemerintahan Pusat dari waktu ke waktu menyerahkan berbagai urusan baru kepada satuan otonomi; (3) pusat mengakui urusan-urusan pemerintahan tertentu yang "diciptakan" atau yang kemudian diatur satuan otonomi baik karena tidak diatur dan diurus pusat maupun atas dasar semacam concurrent power; (4) membiarkan suatu urusan yang secara tradisional atau sejak semula dikenali sebagai fungsi pemerintahan yang diatur dan diurus satuan otonomi. ${ }^{12}$

${ }^{8}$ Ni'Matul Huda, "Hukum Pemerintahan Daerah", (Bandung: Nusa Media, 2009), hal. 31.

${ }^{9}$ Ibid., hal. 29.

${ }^{10}$ Op. Cit., hal. 21.

${ }^{11}$ Bagir Manan, "Menyongsong Fajar Otonomi Daerah", (Yogyakarta: Pusat Studi Hukum (PSH) Fakultas Hukum UII, 2005), hal. 32-36.

${ }^{12}$ Ibid., hal. 35 . 
Undang Undang (UU) Nomor 32 Tahun 2004 merumuskan desentralisasi sebagai penyerahan wewenang pemerintahan oleh pemerintah kepada daerah otonom untuk mengatur dan mengurus urusan pemerintahan dalam sistem Negara Kesatuan Republik Indonesia (Pasal 1 angka 7 UU No. 32/2004). Asas desentralisasi diimplementasikan dalam bentuk Otonomi Daerah yang diartikan sebagai hak untuk mengurus rumah tangga sendiri. ${ }^{13}$ UU Nomor 32 Tahun 2004 menegaskan pengertian otonomi daerah sebagai hak, wewenang, dan kewajiban daerah otonom untuk mengatur dan mengurus sendiri urusan pemerintahan dan kepentingan masyarakat setempat sesuai dengan peraturan perundang-undangan (Pasal 1 angka 5 UU No. 32/2004).

Penyelenggaraan otonomi daerah dilakukan bersamaan dengan penyelenggaraan otonomi desa atau yang disebut dengan nama lain adalah kesatuan masyarakat hukum yang memiliki batas-batas wilayah yang berwenang untuk mengatur dan mengurus kepentingan masyarakat setempat, berdasarkan asal-usul dan adat istiadat setempat yang diakui dan dihormati dalam sistem Pemerintahan Negara Kesatuan Republik Indonesia (Pasal 1 angka 12 UU No. 32/2004). Landasan pemikiran dalam pengaturan mengenai desa adalah keanekaragaman, partisipasi, otonomi asli, demokratisasi dan pemberdayaan masyarakat (Penjelasan Umum UU No. 32/2004).

Konvensi Hukum Laut 1982 telah diratifikasi oleh Indonesia dengan dikeluarkannya UU Nomor 17 Tahun 1985 tentang Pengesahan United Nations Convention on The Law of The Sea 1982. Dengan ditetapkannya UU Nomor 17 Tahun 1985, maka UNCLOS telah menjadi Hukum Nasional Indonesia, dan mengikat seluruh bangsa Indonesia, baik Pemerintah maupun rakyatnya. Tindak lanjut dari penerimaan Konvensi Hukum Laut Tahun 1982 sebagai hukum nasional Indonesia diwujudkan melalui penetapan UU Nomor 6 Tahun 1996 tentang Perairan Indonesia, dimana ketiga prinsip penarikan garis pangkal dalam Konvensi Hukum Laut 1982 secara mutatis mutandis mendapat pengaturan dalam undang undang ini.

Pasal 5 ayat (1) UU Nomor 6 Tahun 1996 menegaskan bahwa "Garis pangkal kepulauan Indonesia ditarik dengan menggunakan garis lurus kepulauan". Dalam hal garis pangkal lurus kepulauan sebagaimana dimaksud dalam ayat (1) tidak dapat digunakan, maka digunakan garis pangkal biasa atau garis pangkal lurus. Dalam hal ini, berpatokan pada pendapat Etty R. Agoes, maka pilihan utama terletak pada penarikan archipelagic straight baseline yang memiliki kedudukan utama

${ }^{13}$ Achmad Yani, "Hubungan Keuangan Antara Pemerintah Pusat Dan Pemerintah Daerah", (Jakarta: Raja Grafindo Persada, 2002), hal. 8. 
dibandingkan dengan normal baseline dan straight baseline yang memiliki kedudukan pengganti bagi suatu negara kepulauan.

Prinsip Negara Kepulauan sebagaimana tertuang dalam UNCLOS yang dipelopori oleh Indonesia melalui Deklarasi Djuanda 1957 belum diadopsi secara benar, sebagaimana terbukti dari berbagai regulasi yang telah dikeluarkan, belum mengakomodir prinsip Negara Kepulauan. Hal ini dapat terlihat menonjol pada UU Nomor 32 Tahun 2004, terutama terkait dengan pengaturan kewenangan daerah untuk mengelola sumberdaya di wilayah laut.

Pasal 18 ayat (4) UU Nomor Nomor 32 Tahun 2004 menegaskan, "Kewenangan untuk mengelola sumberdaya di wilayah laut paling jauh 12 (dua belas) mil laut diukur dari garis pantai ke arah laut lepas dan atau ke arah perairan kepulauan untuk provinsi dan 1/3 (sepertiga) dari wilayah kewenangan provinsi untuk kabupaten/kota". Hal ini menampakkan bahwa UU Nomor 32 Tahun 2004 menerapkan prinsip penarikan garis pangkal biasa (normal baseline), sehingga mengabaikan prinsip garis pangkal lurus (straight baseline) dan prinsip garis pangkal lurus kepulauan (archipelagic straight baseline). Penerapan prinsip penarikan garis pangkal biasa (normal baseline) dalam pasal 18 UU Nomor 32 Tahun 2004, justru menimbulkan ketidak-adilan dalam rangka penyelenggaraan otonomi daerah di Indonesia, mengingat adanya perbedaan karakteristik daerah.

Prinsip Negara Kepulauan mestinya diadopsi secara mutatis mutandis untuk dirumuskan pada pengaturan wilayah kewenangan daerah otonom dalam pengelolaan sumberdaya alam di laut berdasarkan UU Nomor 17 Tahun 1985. Hal ini akan menampakkan adanya harmonisasi antara hukum internasional dan hukum nasional Indonesia melalui adopsi Prinsip Negara Kepulauan menjadi Prinsip Daerah (Provinsi, Kabupaten/Kota) Kepulauan bagi daerah dengan karakteristik kepulauan karena karakteristik wilayah dimana luas wilayah laut yang lebih besar dari luas wilayah darat. Dalam konteks ini, kebutuhan akan peraturan perundang-undangan yang harmonis dan terintegrasi menjadi sangat diperlukan untuk mewujudkan ketertiban, menjamin kepastian dan perlindungan hukum. ${ }^{14}$

Pentingnya prinsip negara kepulauan diadopsi dan dijabarkan menjadi prinsip Daerah Kepulauan telah mendapat perhatian dari Daerah-daerah Provinsi yang berkarakteristik kepulauan. Pada tanggal 10 Agustus 2005, 7 (tujuh) Gubernur dan Ketua Dewan Perwakilan Rakyat Daerah (DPRD) dari Provinsi Kepulauan bertemu di Ambon, dan menghasilkan Deklarasi Ambon dengan latar belakang pemikiran

14 Kusnu Goeniadhie, "Harmonisasi Hukum Dalam Perspektif Perundang-Undangan", (Suabaya: JP Books, 2006), hal. 3. 
bahwa, (1) penegasan kesatuan daratan dan lautan (tanah-air) adalah falsafah serta pandangan bangsa Indonesia mengenai laut sebagai penghubung yang melahirkan prinsip Negara Kepulauan (archipelagic state principles); (2) konsepsi Negara Kepulauan dalam Konvensi Hukum Laut 1982, diperjuangkan oleh Pemerintah dan masyarakat Indonesia, telah menjadikan wilayah Provinsi Kepulauan sebagai tolok ukur adanya pengakuan prinsip Negara kepulauan; (3) pengakuan prinsip Negara Kepulauan hendaknya diimplementasikan menjadi prinsip daerah (provinsi kepulauan); (4) sumber daya alam di laut pada Provinsi Kepulauan mampu memberikan kontribusi yang sangat besar bagi pembangunan masyarakat Indonesia, tetapi tidak mendapat imbalan yang proporsional bagi pembangunan daerah yang mensejahterakan masyarakat. ${ }^{15}$

Atas dasar pemikiran di atas, maka Deklarasi Ambon dengan tegas menegaskan "memintakan Pemerintah Indonesia untuk mewujudkan pengakuan yuridis terhadap Provinsi Kepulauan melalui berbagai regulasi yang dibutuhkan untuk mempercepat proses pembangunan daerah, demi terwujudnya kesejahteraan rakyat. $^{16}$

Upaya hukum yang dilakukan dalam rangka pengakuan yuridis Daerah (Provinsi) Kepulauan, tidak dimaksudkan untuk menuntut otonomi khusus melainkan adanya suatu pengakuan dan perlakuan khusus bagi daerah-daerah (provinsi) yang memiliki karakteristik kepulauan. Dalam hal ini, ada hal yang harus berbeda perlakuan pada daerah-daerah yang wilayahnya lebih luas dari daratan, seperti kabupaten/kota dan provinsi kepulauan.

Substansi pengaturan hukum daerah kepulauan, berkaitan dengan tiga permasalahan pokok, (1) Harmonisasi Hukum; (2) Pembaharuan Hukum dan (3) Karakteristik Hukum.

\section{Harmonisasi Hukum}

Harmonisasi hukum dikembangkan dalam ilmu hukum untuk menujukkan bahwa dalam dunia hukum, baik peraturan perundang-undangan maupun kebijakan pemerintah dan hubungan diantara keduanya terdapat keanekaragaman yang dapat mengakibatkan disharmoni. Kemajemukan sistem hukum di Indonesia juga sangat

\footnotetext{
${ }^{15}$ Badan Kerjasama (BKS) Provinsi Kepulauan, "Draft Akademik Rancangan Undang Undang Daerah Kepulauan", (Ambon 2009), 50.

${ }^{16}$ Ibid., hal. 51.
} 
potensial menimbulkan disharmoni hukum. Dalam konteks pengaturan hukum terhadap daerah kepulauan, maka potensi terjadinya disharmoni hukum dapat dilihat pada faktor-faktor, (1) perbedaan pengaturan dalam undang-undang yang mencerminkan disharmoni antara hukum internasional dan hukum nasional; (2) pertentangan antara hukum nasional dengan hukum adat yang berlaku mengenai pengaturan wilayah laut; (3) pluralisme dalam pengaturan, penerapan dan penegakan hukum di wilayah laut; (4) perbedaan kepentingan dan perbedaan penafsiran dari para pemangku kepentingan di wilayah laut; (5) kesenjangan antara pemahaman hukum dan pemahaman teknis mengenai pengaturan kewenangan daerah di wilayah laut; (6) kendala hukum yang dihadapi dalam penerapan peraturan perundangundangan yang terdiri atas mekanisme pengaturan, administrasi pengaturan, antisipasi terhadap perubahan dan penegakan hukum; (7) hambatan hukum terkait dengan tumpang tindih kewenangan dan benturan kepentingan.

Disharmoni hukum dalam konteks kewenangan pemerintahan daerah di wilayah laut, mengharuskan adanya harmonisasi hukum. Rudolf Stammler mengemukakan suatu konsep fungsi hukum bahwa tujuan dan fungsi hukum adalah harmonisasi berbagai maksud, tujuan dan kepentingan antara individu dengan individu dan antara individu dengan masyarakat. ${ }^{17}$ Dalam konteks ini, prinsip-prinsip hukum yang adil mencakup harmonisasi antara maksud dan tujuan dari kepentingan perorangan serta maksud dan tujuan dari kepentingan umum. Maksud dan tujuan serta kepentingan terdiri atas dua unsur yaitu, saling menghormati dan partisipasi. ${ }^{18}$

Langkah harmonisasi hukum dalam pengaturan daerah kepulauan yang dilakukan melalui, (1) identifikasi letak atau posisi disharmoni hukum di dalam peraturan perundang-undangan; (2) identifikasi penyebab terjadinya disharmoni hukum; (3) melakukan penemuan hukum dengan metode penafsiran dan metode konstruksi hukum untuk mengubah keadaan hukum yang disharmoni menjadi harmoni; (4) melakukan penalaran hukum agar hasil penafsiran dan konstruksi hukum tersebut masuk akal dan memenuhi unsur logika; dan (5) penyusunan argumentasi yang rasional untuk mendukung dan menjelaskan hasil penafsiran hukum, konstruksi hukum dan penalaran hukum. ${ }^{19}$

${ }^{17}$ Husnu Goesniadhie, Op .Cit., hal. 62.

${ }^{18}$ Theo Huijbers, "Filsafat Hukum Dalam Lintasan Sejarah", (Yogyakarta: Kanisius, 1995), hal. 150 .

19 Jason Patlis dkk (Penyunting), "Menuju Harmonisasi Sistem Hukum Sebagai Pilar Pengelolaan Pesisir Indonesia", (Jakarta: tanpa penerbit, 2005), hal. xxi. 
Harmonisasi hukum dalam pengaturan daerah kepulauan secara substansial dilakukan berbasis UUDNRI TH 1945. Hall ini penting, karena UUDNRI TH 1945 sebagai hukum dasar dalam kehidupan berbangsa dan bernegara memuat aturanaturan dasar yang dapat dipergunakan dalam pengaturan hukum daerah kepulauan. Dalam kerangka pengaturan hokum daerah kepulauan, perlu diperhatikan dan diharmonisasikan pasal-pasal yang menjadi dasar penyusunan peraturan perundangundangan dengan rumusan kaedah/norma dalam peraturan perundang-undangan yang berlaku sebagai hukum positif.

Pasal 18 ayat (4) UU Nomor 32 Tahun 2004, terkait dengan pengaturan kewenangan daerah di wilayah laut menampakkan adanya disharmoni dengan pasalpasal dalam UUDNRI TH 1945. Dalam hal ini perintah dari pasal-pasal dalam UUDNRI TH 1945 belum dijabarkan secara konkrit dalam UU Nomor 32 Tahun 2004 tersebut. Makna pengaturan dalam pasal-pasal UUDNRI TH 1945, belum dianalisis secara komprehensif, untuk melahirkan pemahaman utuh menyeluruh dan komprehensif dalam kerangka pengaturan terhadap kewenangan daerah otonom di wilayah laut.

Pasal 25A UUDNRI TH 1945 menegaskan bahwa "Negara Kesatuan Republik Indonesia adalah sebuah Negara Kepulauan yang berciri Nusantara dengan wilayah yang batas-batas dan hak-haknya ditetapkan dengan undang undang". Pendekatan pengaturan pemerintahan daerah terkait dengan kewenangan daerah di wilayah laut berdasarkan karakteristik kepulauan yang berciri "nusantara" (pulau-pulau diantara lautan yang luas) akan mewujudkan kesejahteraan masyarakat secara substansial. Hal ini penting mengingat karakteristik dan permasalahan yang dihadapi oleh pemerintahan daerah kepulauan, seperti, (a) Luas wilayah laut yang lebih besar dari wilayah daratan; (2) Dari segi persebaran demografis, penduduk wilayah kepulauan biasanya bersifat relatif sedikit dan penyebarannya tidak merata; (3) Dari segi sosial budaya, komunitas-komunitas di wilayah kepulauan tersegregasi dalam permukiman menurut territorial suatu pulau; (4) Dari segi ketersedian sumber daya alam, relatif beragam; (5) Dari segi sistim kehidupan, ditentukan oleh tingkat isolasi geografis dengan keunikan habitat (endemis) dan keanekaragamaan biotik (biodiversitas); (6) Dari segi sosial ekonomi, aktivitas ekonomi, jenis dan derajat dinamika ekonomi umumnya terbatas dan berskala kecil, serta belum didukung oleh jaringan distribusi dan pemasaran secara memadai; (7) Dari segi lingkungan, sumber daya lingkungan kecil, rentan terhadap perubahan (entrophy), rawan bencana alam (gelombang di permukaan laut; (8) Dari segi biogeografis, terdapat potensi keanekaragaman hayati darat dan perairan sekitar pulau-pulau (kecil); (9) Hampir semua Provinsi Kepulauan 
berada pada wilayah/kawasan Perbatasan Negara, yang memiliki pulau kecil

Pengaturan hukum terhadap daerah kepulauan hendaknya dilakukan dalam konteks Pasal 18 ayat (1) yang menegaskan "Negara Kesatuan Republik Indonesia dibagi atas daerah-daerah provinsi dan daerah provinsi itu dibagi atas kabupaten dan kota, yang tiap-tiap provinsi, kabupaten dan kota itu mempunyai pemerintahan daerah yang diatur dengan undang-undang". Pasal 18A ayat (1) UUDNRI TH 1945, "Hubungan wewenang antara pemerintah pusat dan pemerintahan daerah provinsi, kabupaten dan kota, atau antara provinsi dan kabupaten dan kota diatur dengan undang-undang dengan memperhatikan kekhususan dan keragaman daerah". Pasal 18B ayat (1) UUDNRI TH 1945, "Negara mengakui dan menghormati satuan-satuan pemerintahan daerah yang bersifat khusus atau bersifat istimewa yang diatur dengan undang-undang" dan Pasal 18B ayat (2) yang mengatur mengenai kesatuan masyarakat hukum adat.

Pengaturan hukum daerah kepulauan, belum terlihat dalam rumusan UU Nomor 32 Tahun 2004, sehingga memperlihatkan adanya disharmoni antara undangundang ini dengan UUDNRI TH 1945. Apabila disharmoni antara UU Nomor 32 Tahun 2004 dengan UUDNRI TH 1945 tidak mendapat perhatian dalam kebijakan regulasi, maka dapat saja terjadi pelanggaran Hak Asasi Manusia (HAM) yang telah mendapatkan pengaturan secara memadai dalam UUDNRI TH 1945. Pasal-pasal dalam UUDNRI yang mengatur hak asasi manusia yang terkait dengan pengaturan hukum daerah kepulauan adalah Pasal 28C ayat (1) (hak mengembangkan diri dalam bidang pendidikan), Pasal 28C ayat (2) (hak memperjuangkan kepentingan kolektif), Pasal 28H ayat (1) (hak hidup sejahtera lahir dan bathin), Pasal 28H ayat (2) (hak mendapat kemudahan dan perlakuan khusus), Pasal 28I ayat (2) (hak bebas dari perlakuan yang bersifat diskriminatif), Pasal 28I ayat (3) (hak atas identitas budaya dan hak masyarakat tradisional).

Harmonisasi hukum dalam pengaturan daerah kepulauan hendaknya dilakukan sesuai prinsip Negara Kepulauan dalam Konvensi Hukum Laut 1982. Konvensi Hukum Laut Tahun 1982 telah mendapat pengakuan sebagai $a$ Constitution of the Oceans, dimana setiap Negara dapat menetapkan berbagai macam zona maritim seperti perairan pedalaman, laut teritorial, zona tambahan, zona ekonomi eksklusif dan landas kontinen, ${ }^{21}$ yang harus diukur mulai dari garis-garis pangkal.

\footnotetext{
${ }^{20}$ BKS Provinsi Kepulauan, Op. Cit., hal. 61.

${ }^{21}$ Etty R. Agoes, Op. Cit., hal. 442.
} 
Ketentuan mengenai penarikan garis pangkal biasa (normal baseline) tertuang dalam Pasal 5 Konvensi Hukum Laut 1982 berwujud garis air rendah sepanjang pantai sebagaimana terlihat pada peta skala besar yang diakui resmi oleh Negara pantai tersebut. Rumusan dalam ketentuan Pasal 5 Konvensi Hukum Laut 1982 ini, sama dengan rumusan dalam Pasal 3 Konvensi Jenewa 1959 tentang Laut Teritorial dan Zona Tambahan (Convention on the Territorial Sea and the Contiguous Zone).

Ketentuan mengenai garis pangkal lurus (straight baseline) ditegaskan dalam Pasal 7 Konvensi Hukum Laut 1982, yang hampir bersamaan dengan Pasal 4 Konvensi Jenewa 1958 tentang Laut Teritorial dan Zona Tambahan. Dalam Pasal 7 ayat (1) Konvensi Hukum Laut 1982, dimana terdapat 2 (dua) syarat geografis yang memungkinkan dapat dipergunakannya penarikan garis pangkal yaitu (1) di tempattempat dinama garis pantainya banyak berliku tajam atau menjorok jauh ke dalam atau lautnya masuk jauh ke dalam; dan (2) apabila terdapat deretan pulau sepanjang pantai atau yang letaknya tidak jauh dari pantai. Pada Pasal 7 ayat (2) Konvensi Hukum Laut 1982, ditambahkan kondisi geografis ketiga yang memungkinkan dilakukannya penarikan garis pangkal lurus yaitu apabila adanya suatu delta atau kondisi alam lainnya garis pantai sangat tidak tetap, maka titik-titik yang tepat dapat dipilih pada garis air rendah yang paling jauh menjorok ke laut untuk melakukan penarikan garis pangkal lurus.

Ketentuan mengenai penarikan garis pangkal lurus kepulauan (archipelagic straight baseline) merupakan bagian pengaturan mengenai konsepsi Negara Kepulauan dalam Konvensi Hukum Laut 1982. Konsepsi Negara Kepulauan merupakan suatu konsepsi baru dalam hukum internasional yang mendapat pengaturan dalam Konvensi Hukum Laut 1982. Dalam Konvensi Hukum Laut 1982 konsepsi ini telah dituangkan ke dalam beberapa asas yang dinamakan asas-asas Negara Kepulauan (archipelagic state principles) sebagaimana tercantum pada Bab IV yang terdiri dari sembilan pasal (Paal 46 - Pasal 54), yang berisi antara lain ketentuan tentang Negara Kepulauan, garis pangkal lurus kepulauan serta status hukum dari perairan kepulauan.

Menurut Hasyim Djalal, 22 "archipelago" sebagai suatu konsepsi geografis menjadi dasar bagi konsepsi archipelagic state yang terdiri dari satu atau beberapa archipelago, sedangkan tidak setiap archipelago menjadi archipelagic state atau tidak harus diperlakukan sebagai archipelagic state. Oleh karena itu, terdapat 3 (tiga) jenis archipelago yaitu, (1) Coastal Archipelago, yang terletak di sepanjang pantai dan yang pada umumnya berdekatan dengan pantai. Hal ini pada dasarnya telah

${ }^{22}$ Op. Cit., hal. 70. 
diselesaikan oleh Konferensi Geneva 1958 tentang laut wilayah yang memungkinkan negara pantai menarik garis-garis dasar dari archipelago yang terletak berdekatan di sepanjang pantai tersebut; (2) Mid-ocean Archipelago yang terletak di tengah laut yang jauh dari pantai suatu negara. Pada dasarnya konsepsi Hukum Internasional mengenai archipelago berasal dari archipelago-archipelago semacam ini yang pada umumnya merupakan suatu gugusan pulau-pulau yang kompak dan yang jarak antara pulau-pulaunya tidak begitu besar; (3) Archipelagic State yaitu suatu gugusan pulaupulau atau beberapa gugusan pulau-pulau yang menjadi suatu negara merdeka. ${ }^{23}$

Ketentuan Pasal 46 Konvensi Hukum Laut 1982 apabila dikaitkan dengan realitas karakteristik Negara Kepulauan Indonesia, memperlihatkan bahwa di dalam Negara Kepulauan Indonesia terdapat daerah-daerah provinsi dengan karakteristik, (1) Coastal archipelago yaitu daerah-daerah provinsi yang mempunyai pulau-pulau di sepanjang pantai utama; misalnya Provinsi Daerah Khusus Ibukota Jakarta, Provinsi Sumatera Utara, Provinsi Sumatera Barat, Provinsi Riau, Provinsi Aceh, Provinsi Papua, Provinsi Papua Barat dan lain-lain; (2) Mid ocean archipelago yaitu daerah-daerah provinsi yang mempunyai pulau-pulau di tengah laut sebagai bagian dari wilayah daerah tersebut; misalnya Provinsi Jawa Timur, Provinsi Sulawesi Selatan, Provinsi Sulawesi Tenggara dan lain-lain; dan (3) Archipelagic Province atau Daerah Provinsi Kepulauan yaitu daerah-daerah yang mempunyai pulau-pulau yang membentuk gugusan pulau; seperi Provinsi Kepulauan Riau, Provinsi Kepulauan Bangka Belitung, Provinsi Nusa Tenggara Barat, Provinsi Nusa Tenggara Timur, Provinsi Sulawesi Utara, Provinsi Maluku Utara dan Provinsi Maluku.

Sebagaimana halnya dengan berbagai negara atau masyarakat bangsa-bangsa yang selalu berubah dan berkembang, maka Indonesia juga sedang mengalami era perkembangan itu, tetapi mengalami masa transisi dalam pengaturan hukum. Masa transisi tersebut meliputi aneka macam bidang kehidupan, baik sosial budaya, ekonomi, politik maupun hukum. Dalam bidang hukum, sedang terjadi perubahan arah dari tatanan hukum tidak tertulis ke arah hukum tertulis, meskipun tidak dapat dihindari bahwa hukum tidak tertulis tetap hidup dan berkembang pada sebagian besar kesatuan masyarakat hukum adat. ${ }^{24} \mathrm{Hal}$ ini penting karena, menurut Lon Fuller, hukum tidak tertulis atau hukum adat didasarkan pada proses interaksi dalam masyarakat, dan kemudian berfungsi sebagai pola untuk mengorganisasikan serta

${ }^{23}$ Ibid., hal. 70-71.

${ }^{24}$ Soerjono Soekamto, "Hukum Adat Indonesia", (Jakarta: Raja Grafindo Persada, 1981), hal. 374. 
memperlancar proses interaksi tersebut, sehingga seringkali hukum adat dinamakan $a$ system of stabilized interactional expectancies. ${ }^{25}$

Di dalam hukum adat yang berlaku pada kesatuan masyarakat hukum adat di Maluku, penentuan batas wilayah laut dilakukan secara berbeda dan berdasarkan karakteristik wilayah dari kesatuan masyarakat hukum adat tersebut. Dalam hal ini, masing-masing kesatuan masyarakat hukum adat menetapkan luas wilayah petuanannya berdasarkan karakteristik tersebut, yang dapat terlihat dalam beberapa pola.

Pertama, batas petuanan kesatuan masyarakat hukum adat di laut ditentukan oleh pola umum yang dianut masyarakat, dimana suatu wilayah petuanan berakhir sampai batas air putih dan air hitam, dimana dasar laut tidak kelihatan dan disebut tohor atau tubir. Kedua, pola penentuan batas petuanan berdasarkan air pasang surut sampai air yang berwarna hitam. Ketiga, pola penentuan batas petuanan laut kesatuan masyarakat hukum adat yang didasarkan pada prinsip sejauh mata memandang atau didasarkan pada batas pandangan mata dari daratan atau pantai.

Pola pengaturan hukum wilayah petuanan laut kesatuan masyarakat hukum adat yang simetris dengan pola pengaturan hukum laut nasional dan internasional, pada dasarnya dapat dipergunakan dalam pengaturan hukum terhadap daerah kepulauan berdasarkan konsepsi Negara Kepulauan sebagaimana terdapat pada Konvensi Hukum Laut 1982. Hal ini penting karena, ketiga pola pengaturan dalam hukum adat yang simetris dengan hukum nasional dan hukum internasional, secara prinsipil didasarkan pada prinsip kesatuan wilayah daratan dan lautan yang merupakan prinsip dasar konsepsi Negara Kepulauan baik pada Deklarasi Djuanda 1957 maupun Konvensi Hukum Laut 1982. Adanya pola pengaturan yang simetris ini apabila diimplementasikan dalam rumusan-rumusan norma pengaturan hukum terhadap daerah kepulauan, akan memungkinkan penerimaan yang memadai dari masyarakat, sehingga memungkinkan tumbuhnya kesadaran untuk menghormati, mematuhi dan melaksanakan bentuk pengaturan itu secara berkualitas dan berlaku efektif.

\section{Pembaharuan Hukum}

Pada dasarnya, pembaharuan hukum dalam kaitan dengan pengaturan daerah kepulauan dilakukan untuk menjawab kompleksitas masyarakat kepulauan yang menjadi objek dalam pengaturan hukum tersebut. Masyarakat pada daerah-daerah

${ }^{25}$ Ibid., hal 375 . 
kepulauan memiliki kompleksitas sosial yang didasarkan pada pulau-pulau kecil yang terpisah jauh oleh lautan yang luas, sehingga menimbulkan segregasi berdasarkan Negeri (baca: Desa) dan Pulau yang menjadi identitas diri. Kompleksitas sosial masyarakat kepulauan memperlihat adanya dinamika interaksi yang menimbulkan ketidak-teraturan dalam masyarakat, karena hukum yang berlaku menimbulkan ketidak-teraturan itu.

Menurut Gunther Teubner, ${ }^{26}$ hukum modern memperlihatkan dominasi negara sebagai pengatur di satu sisi dan meningkatkan kesejahteraan rakyat di sisi yang lain, menyebabkan lahirnya konsep negara kesejahteraan (welfare state) dan negara pengatur (regulatory state). Salah satu persoalan yang dialami oleh hukum modern dewasa ini adalah adanya "krisis" rasionalitas formal. Oleh karena itu, perlu dilakukan rematerialisasi hukum. Timbulnya rematerialisasi hukum karena adanya krisis rasionalitas formal pada hukum modern.

Krisis rasionalitas hukum formal dalam pengaturan daerah kepulauan, terjadi karena secara nasional, ketentuan hukum dalam regulasi nasional belum sepenuhnya mengadopsi secara mutatis mutandis prinsip Negara Kepulauan, baik dalam Konvensi Hukum Laut 1982 maupun Pasal 25 UUDNRI TH 1945. Dalam konteks ini, kebijakan Pemerintah Indonesia masih tetap berorientasi pada daerah-daerah dengan karakteristik kontinental (karakteristik terestrial dan terestrial akuatik). Akibatnya, daerah-daerah yang memiliki karakteristik akuatik terestrial (kepulauan) dengan wilayah laut yang luas, kurang diperhitungkan karena masyarakatnya berada dalam suatu tatanan yang segregatif.

Konteks masyarakat kepulauan di atas, penting diletakkan dalam kaitan dengan pendapat Niklas Luhmann yang mengidentifikasi tiga prinsip organisasi yang mendominasi masyarakat yaitu segmentasi, stratifikasi dan perbedaan fungsi. Ketiga prinsip tersebut menghasilkan konfigurasi khusus mengenai hukum yang mengarah pada arahan yang lebih spesifik dalam evolusi hukum. ${ }^{27}$ Oleh karena itu menurut Luhmann, krisis hukum hendaknya dikembangkan dalam transisi dari pembagian tingkatan ke perbedaan fungsional masyarakat, yang menuntut transisi yang paralel dari peraturan perundang-undangan yang dihasilkan dalam pemerintahan. Menurut Luhmann, yang diperlukan adalah abstraksi yang lebih tinggi dari pemikiran fungsionalisasi dan refleksi dari sistem peraturan perundang-undangan. ${ }^{28}$ Dalam hal

${ }^{26}$ Gunther Teubner; "Substantive and Reflexive Element In Modern Law", dalam Law and Society Review, Volume 17, Nomor 2, Tahun 1983, 265.

${ }^{27}$ Ibid., hal. 263. 
ini, konsep pemikiran Luhmann dikembangkan atas dasar tiga asumsi dasar yaitu dinamis, mekanis dan menunjuk pada sistem evolusi. Konsep Luhmann merupakan suatu perpaduan yang kompleks antara sistem dan lingkungan.

Rematerialisasi hukum nasional dalam menjawab tantangan pembangunan untuk mengatasi kompleksitas masyarakat kepulauan, hendaknya diikuti dengan penataan hukum daerah yang rasional substantif dalam suatu formulasi hukum formal yang rasional.

Rematerialisasi hukum nasional maupun daerah pada dasarnya dilakukan berdasarkan pembaharuan hakikat hukum. Hakikat hukum menurut Achmad Ali, ${ }^{29}$ merupakan hubungan timbal balik dari tiga komponen sistem hukum (struktur hukum, substansi hukum, dan kultur atau budaya hukum) dengan fungsi hukum dan tujuan hukum. Ketiga komponen sistem hukum (struktur hukum, substansi hukum dan kultur atau budaya hukum) menjadi satu teori sistem hukum (legal system). Akan tetapi, menurut Achmad Ali, ${ }^{30}$ perlu ditambahkan lagi dua unsur sistem hukum yaitu, (1) Profesionalisme, yang merupakan unsur kemampuan dan keterampilan secara person dari sosok-sosok penegak hukum; dan (2) Kepemimpinan, juga merupakan sunsur kemampuan dan keterampilan secara person dari sosoksosok penegak hukum, utamanya kalangan petinggi hukum.

Masyarakat pada daerah-daerah (provinsi) kepulauan hanya menghendaki adanya pengakuan dari Pemerintah Republik Indonesia terhadap adopsi penerapan prinsip negara kepulauan dalam Konvensi Hukum Laut 1982 dalam penentuan wilayah kewenangan daerah otonom di laut, sehingga terjadi perbedaan perlakuan berdasarkan karakteristik wilayah. Pada sisi lain, masyarakat pada daerah-daerah provinsi kepulauan tetap menghormati dan menghargai hak-hak atas penggunaan laut sebagaimana telah diatur dalam Konvensi Hukum Laut 1982 maupun hukum nasional Indonesia yang berkaitan dengan prinsip Wawasan Nusantara. Dalam hal ini, hak nelayan tradisional dari daerah-daerah yang bukan provinsi kepulauan tetap dihormati dan dilindungi, begitu juga hak-hak yang diberikan dalam hukum internasional. Oleh karena itu, pembaharuan hukum dalam konteks pengaturan hukum terhadap kewenangan daerah otonom di wilayah laut, hendaknya dilakukan terhadap komponen-komponen sistem hukum tersebut.

${ }^{28}$ Ibid., hal. 264.

29 Achmad Ali, "Menguak Teori Hukum (Legal Theory) dan Teori Peradilan (Judicial Prudence) Termasuk Interpretasi Undang Undang (Legis Prudence), (Vol 1, Pemahaman Awal)", (Jakarta: Prenada Media Group, 2009), hal. 207.

${ }^{30}$ Ibid., hal. 204. 
Pembaharuan hukum dalam realitas dunia globalisasi yang memperlihatkan adanya pluralisme hukum. Oleh karena itu pengaturan hukum hendaknya diletakkan dalam konteks teori hukum yang menjawab realitas dunia globalisasi yaitu triangular concept of legal pluralism (konsep segitiga pluralisme hukum) sebagaimana dikemukanan oleh Werner Menski. ${ }^{31}$ Werner Menski menolak konsep anti pluralist alias konsep unification vision alias vision of globalised uniformisation, made by American led initiatives, yang pada dasarnya berupaya menyeragamkan visi internasional dunia global di bawah satu visi ala Amerika, mengenai isu-isu krusial menyangkut hukum, keadilan dan hak asasi manusia. ${ }^{32} \mathrm{Di}$ Indonesia, sudah lama menjadi sasaran dan berhasil ditularkan visi universalitas ini, baik dalam bidang HAM dengan mengabaikan sisi partikularisasi HAM yang sebenarnya merupakan sesuatu yang sangat plural, maupun dalam kebijakan pembangunan dan pembiayaan pembangunan yang mengabaikan karakteristik wilayah daerah (provinsi maupun kabupaten/kota).

\section{Karakteristik Hukum}

Pengaturan hukum terhadap daerah kepulauan hendaknya dilakukan dalam konteks karakteristik peraturan perundang-undangan yang berbasis hukum responsif. Karakteristik hukum peraturan perundang-undangan yang menonjol adalah berlaku sebagai hukum positif Indonesia. Hukum positif merupakan aturan hukum yang ketentuan-ketentuannya berlaku di suatu saat, waktu dan tempat tertentu, ditaati oleh manusia dalam pergaulan hidup selama timbulnya ketentuan itu berdasarkan kesadaran hukum masyarakat, disamping cara yang digunakan oleh pergaulan hidup itu untuk mencapai keadilan. ${ }^{33}$ Hukum positif merupakan terjemahan dari Ius Constitutum, yang dibedakan dengan hukum yang direncanakan atau Ius Constituendum, dimana konsepsi pemikiran mengenai suatu aturan hukum yang dapat berlaku sebagai hukum positif.

Pengaturan hukum terhadap daerah kepulauan dengan mengadopsi prinsip Negara Kepulauan dalam Konvensi Hukum Laut 1982 merupakan suatu Ius

${ }^{31}$ Ibid., hal. 184.

${ }^{32}$ Ibid., hal. 514.

${ }^{33}$ Abdul Djamali, "Pengantar Hukum Indonesia", (Jakarta: Rajawali, 1984), hal. 7-8. 
Constituendum yang diharapkan menjadi Ius Constitutum melalui peraturan perundang-undangan nasional.

Untuk menjadi Ius Constitutum, pengaturan hukum terhadap kewenangan daerah otonom di wilayah laut harus memenuhi wujud nyata peraturan perundangundangan sebagai hukum positif. Dalam konteks ini, hukum positif Indonesia berwujud peraturan perundang-undangan yang, (a) dibuat oleh lembaga-lembaga yang berwenang sesuai dengan ketentuan hukum, tata cara, dan prosedur yang berlaku; (b) bersifat mengatur dan memaksa; (c) dapat dipaksakan berlakunya oleh aparat penegak hukum; dan (d) memiliki sanksi hukum. Hukum positif Indonesia juga mencakup hukum adat yang berlaku bagi berbagai masyarakat adat di Indonesia. Sebagai hukum positif Indonesia, maka hukum adat merupakan hukum yang, (a) dibuat oleh masyarakat hukum adat; (b) bersifat rnengatur dan memaksa; (c) berlakunya dapat dipaksakan oleh lembaga-lembaga adat yang berwenang; dan (d) memiliki sanksi hukum. ${ }^{34}$ Dalam hal ini, hukum adat, apabila menjadi hukum positif yang berlaku secara menyeluruh, maka nilai-nilai hukum adat tersebut dapat menjadi norma hukum dalam peraturan perundang-undangan nasional.

Untuk mengatasi kritik atas dasar realitas krisis otoritas hukum, maka Philippe Nonet dan Philip Selznick (1978) mengajukan model hukum responsif. Model hukum responsif menempatkan hukum sebagai sarana respons terhadap ketentuanketentuan sosial dan aspirasi publik. Sesuai dengan sifatnya yang terbuka, maka model hukum responsif mengedepankan akomodasi untuk menerima perubahanperubahan sosial demi tercapainya keadilan dan emansipasi publik. Dalam konteks ini Nonet dan Selznick memberi perhatian pada variabel-variabel yang berkaitan dengan hukum, seperti peranan paksaan dalam hukum, hubungan antara hukum dengan politik, negara, tatanan moral, tempat diskresi, peranan tujuan dalam keputusan hukum, partisipasi, legitimasi dan kondisi-kondisi kepatuhan terhadap hukum. ${ }^{35}$ Variabel-variabel hukum yang menjadi fokus pembahasan hukum responsif dari Nonet dan Selznick, apabila diletakkan dalam konteks pengaturan kewenangan daerah otonom di wilayah laut terkait dengan adopsi dan penerapan prinsip Negara Kepulauan, memperlihatkan adanya sinergitas. Dalam hal ini, hukum positif yang berlaku selama ini belum memperlihatkan variabel-variabel sebagaimana dianalisis Nonet dan Selznick. Sebagai contoh dapat dikemukakan variabel tujuan hukum sebagaimana dalam hukum yang berlaku belum diletakkan dalam kerangka

${ }^{34}$ Ibid., hal. 136-137.

${ }^{35}$ Bernard Tanya dkk, "Teori Hukum, Strategi Tertib Manusia Lintas Ruang Dan Generasi", (Surabaya: CV Kita, 2007), hal. 238-239. 
mensejahterakan masyarakat yang berada pada daerah-daerah kepulauan (akuatik terestrial), karena adanya perlakuan yang sama dengan daerah kontinental (terestrial).

Tatanan hukum responsif menekankan pada, (1) keadilan substantif sebagai dasar legitimasi hukum; (2) peraturan merupakan sub-ordinasi dari prinsip dan kebijakan; (3) pertimbangan hukum harus berorientasi pada tujuan dan akibat bagi kemaslahatan masyarakat; (4) penggunaan diskresi sangat dianjurkan dalam pengambilan keputusan hukum dengan tetap berorientasi pada tujuan; (5) memupuk sistem kewajiban sebagai ganti sistem paksaan; (6) moralitas kerjasama sebagai prinsip moral dalam menjalankan hukum; (7) kekuasaan didayagunakan untuk mendukung vitalitas hukum dalam melayani masyarakat; (8) penolakan terhadap hukum harus dilihat sebagai gugatan terhadap legitimasi hukum; dan (9) akses partisipasi publik dibuka lebar dalam rangka integrasi advokasi hukum dan sosial. ${ }^{36}$

\section{Penutup}

Substansi pengaturan hukum terhadap daerah kepulauan, apabila dikaji dari perspektif prinsip Negara Kepulauan, belum menampakkan sinkronisasi harmonisasi hukum, pembaharuan hukum dan karakteristik hukumnya. Belum sinkronnya substansi pengaturan hukum disebabkan, (a) hukum positif Indonesia belum mengadopsi prinsip pembedaan dalam Konvensi Hukum Laut 1982; (b) belum adanya pembaharuan hukum yang menjawab kompleksitas masyarakat kepulauan dengan nilai-nilai hukum adatnya yang positif; (c) belum terlihat karakteristik hukum responsif berbasis nilai-nilai hukum adat masyarakat kepulauan.

Sehubungan dengan kesimpulan di atas, maka ngaturan hukum terhadap daerah kepulauan hendaknya mengadopsi prinsip Negara Kepulauan dan memperhatikan nilai-nilai hukum adat yang berlaku dalam masyarakat kepulauan. Untuk itu Pemerintahan Daerah Kepulauan, hendaknya membuat model penataan ruang laut, pesisir dan pulau-pulau kecil berbasis nilai-nilai hukum adat yang disesuaikan dengan kepentingan ekonomi, sosial, budaya dan politik, sehingga dapat menjadi model pengembangan dan pengaturan wilayah laut.

${ }^{36}$ Ibid., hal. 241. 


\section{Daftar Pustaka}

Ali, Achmad. Menguak Tabir Hukum, Bogor Selatan: Ghalia Indonesia, 2008. Agoes, Etty R.. "Praktik Negara-Negara Atas Konsepsi Negara Kepulauan", dalam Jurnal Hukum Internasional, Lembaga Pengkajian Hukum Internasional Fakultas Hukum Universitas Indonesia, Jakarta, Volume 1 Nomor 3, April 2004.

Assiddiqie, Jimly. Konsolidasi Naskah UUD 1945 Setelah Perubahan Keempat, Jakarta: Pusat Studi Hukum Tata Negara, Fakultas Hukum UI, 2002.

Badan Kerjasama (BKS) Provinsi Kepulauan. Draft Akademik Rancangan Undang Undang Daerah Kepulauan, Ambon, 2009.

Djalal, Hasyim. Perjuangan Indonesia Di Bidang Hukum Laut, Bandung: Binacipta, 1979.

Djamali R., Abdoel. Pengantar Hukum Indonesia, Jakarta: Rajawali, 1984.

Friedman, Lawrence. The Legal System, A Social Science Perspective. New York Russell Sage Foundation, 1997.

Goesniadhie S., Kusnu. Harmonisasi Hukum Dalam Perspektif Perundangundangan, Surbaya: JP Books, 2006.

Huda, Ni'Matul. Hukum Pemerintahan Daerah, Bandung: Nusa Media, 2009.

Huijbers, Theo. 1995. Filsafat Hukum Dalam Lintasan Sejarah, Yogyakarta: Kanisius, 1995.

Kusumaatmadja, Mochtar. Hukum Laut Internasional. Bandung: Binacipta, 1986. Alumni, 2003.

Manan, Bagir. Menyongsong Fajar Otonomi Daerah, Yogyakarta: Pusat Studi Hukum (PSH), Fakultas Hukum UII, 2005.

Mauna, Boer. Hukum Internasional, Pengertian, Peranan dan Fungsi Dalam Era Dinamika Global, Bangung: Alumni, 2003.

Patlis, Jason, dkk (Penyunting). Menuju Harmonisasi Sistem Hukum Sebagai Pilar Pengelolaan Pesisir Indonesia. Kementerian Perencanaan 
Pembangunan Nasional/Bappenas, Kementerian Kelautan dan Perikanan bekerjasama dengan Mitra Pesisir/Coastal Resources Management Project II, Jakarta, 2005.

Soekanto, Soerjono. Hukum Adat Indonesia, Jakarta: Raja Grafindo Persada, 1981.

Starke, J.G. An Introduction To International Law, London: Butterworths, 1984.

Tanya, Bernard dkk. Teori Hukum, Strategi Tertib Manusia Lintas Ruang dan Generasi, Surabaya: CV Kita, Surabaya, 2007.

Teubner, Gunther. Substantive and Reflexive Element In Modern Law; dalam Law and Sociaty Review, Volume 17, Number 2, 1983.

Yani, Achmad. Hubungan Keuangan Antara Pemerintah Pusat dan Pemerintah Daerah, Jakarta: Raja Grafindo Persada, 2002.

. Menguak Teori Hukum (Legal Theory) dan Teori Peradilan (Judicial Prudence) Termasuk Interpretasi Undang Undang (Legis Prudence) (Vol. 1, Pemahaman Awal), Jakarta: Prenada Media Group, 2009. 